\title{
The Literature Review of Raised Funds to Buy Financial Products
}

\author{
Xing Jiang \\ Department of Management, Jinan University, Guangzhou, China \\ Email:jxing_shine@163.com
}

How to cite this paper: Jiang, X. (2018). The Literature Review of Raised Funds to Buy Financial Products. Journal of Financial Risk Management, 7, 55-64. https://doi.org/10.4236/jfrm.2018.71004

Received: February 5, 2018

Accepted: March 23, 2018

Published: March 26, 2018

Copyright (C) 2018 by author and Scientific Research Publishing Inc. This work is licensed under the Creative Commons Attribution International License (CC BY 4.0).

http://creativecommons.org/licenses/by/4.0/

\begin{abstract}
Since 2015, the speed of A-share IPO review has been accelerating. The raised funds by listed companies hit record highs in many different ways. After the stock investment, investors have also begun to pay more attention to the whereabouts of the raised funds. Because of the phenomenon of frequent purchases of financial products by raised funds in the past three years, the academic community set off a wave of scholarship fund-raising academic research after 2000. This article discussed the existing literature theory on listed companies using raised funds to purchase trust financing. And this article not only gave a summary to the research methods and conclusions of the raised funds buying trust financing or financing products, but also reviewed the research about investment efficiency after the raised funds target project changed. At last, this paper gave several directions for the future study about raised funds.
\end{abstract}

\section{Keywords}

Raised Funds, Trust Financing, Financial Products, Investment Efficiency

\section{Introduction}

On October 31, 2016, the Guangzhou Daily published an article which is titled "Invest This Listed Company Should Be Careful, Who Buy Financial Products by Raised Funds". ${ }^{1}$ This article revealed the crazy phenomenon that listed companies bought financial products by funds which were raised for special target project in the capital market once again. Zhou (2006) said that the level of over-financing in China's listed companies is quite high. According to the flush statistics, from the beginning of 2016 to October 18, the listed companies in

${ }^{1}$ Guangzhou Daily. Invest This Listed Company Should Be Careful, Who Buy Financial Products by Raised Funds. http://www.xinhuanet.com/fortune/2016-10/31/c_1119816483.htm, 2016-10-31 
Shanghai and Shenzhen have purchased total 2703 wealth management products, and the total funds used for purchasing wealth management products is about 248.135 billion yuan. In fact, this weird phenomenon did not emerge in recent years. It can be traced back to the fanatical pursuit of trust management in the capital market since 1999. As Ba (2001) said, then on the one hand, listed company crazily raised money by the additional issuance, rights issue, convertible bonds, etc. On the other hand they use a huge amount of money in entrusted financial management. However, with the sluggish capital market, this phenomenon has gradually decreased since 2003. Listed companies have gradually purchased banking financial products since 2008. In 2008, there were only 4 listed companies whom bought the bank's wealth management shares in Shanghai and Shenzhen Stock Exchanges. From September 1 to October 19, 2016, 167 listed companies in Shanghai and Shenzhen Stock Exchanges invested almost 40.005 billion yuan in 344 kinds of trusts and financial products. Regardless of the number of listed companies buying wealth management products or the size of the purchase of wealth management products, there has been a unilateral upward trend. The rapid growth has brought more confusion and concern. On the one hand it is the questioned about the source of funds which listed companies buy financial products, on the other hand it is about the risk of listed companies to buy financial products.

For the purchase of financial products, there are three main sources of funds: own idle funds, idle to raise funds, the combination of own idle funds and idle to raise funds. Although all listed companies have announced that they are using the idle special raised funds, but in the course of operation found that listed companies have voluntarily idle and misappropriation of raised funds, these two forms of funds also constitute the major source of funds which listed companies buy financial product. Although it is legal to purchase wealth management products from the idle special raised funds after December 2012, it is always illegal to divert funds. However, listed companies use oversubscribed raise or refinance to make funds which are not invested in the main business, but all invested in low-interest financial products, in to some extent, violate the wishes of investors.

Listed companies increasingly use idle funds to buy wealth management products. Although this behavior complies with the law, the market and investors are generally questioned and worried. The concerns from the market and investors are the decline of the business capacity while listed companies would not use raised funds for the company's main business or the projects noticed in the official announcement. Meanwhile, the most important is that the investor Investment efficiency and returns on investment are declining. As the phenomenon of using financial capital to buy wealth management products becomes more and more widespread, more and more listed companies are tempted to divert or even raise money in the name of the unwarranted from capitalist market. Thereby, this would trigger investors to question the function of capital markets. Because of the legitimate but unreasonable special phenomenon involving many 
entities of interest and a wide range of influence, the research on it becomes more and more important.

From December 2012 onwards, the use of special idle funds to buy wealth management products begins to have legitimacy. In general, its research is still relatively small. On the one hand, the study of idle funds tends to be the remainder of the business investment, less involved in fund-raising. On the other hand, in early 21 st century the most research is trust-based financial management. The research on purchasing behavior of wealth management products rise in 2009. Due to the low availability of the data, its research is relative less.

The special regulation of special raised funds is very strict in western capital market, and has formed a complete trust management system. However, China's recognition of the legality of the purchase of wealth management products by raised funds is late, and there is insufficient supervision on the use and change of special raised funds for enterprises. And the great varieties of financial products designed by the banks and other financial institutions have also deepened the regulatory difficulty. It makes the use of special raised funds by listed companies to have Chinese characteristics during buying financial products. So, research on this issue will help the economic theory of the local use.

\section{The Literature Review of Trust Financing}

As listed companies to buy bank wealth management products gradually emerged after 2011, so we have few related studies. However, the research in this area can learn from the literature on entrusted money management. Trust companies and purchase wealth management products are essentially the same. They both belong to free cash flow areas. Meanwhile, they are entrusted to third-party management of assets. Therefore, the commission of financial management literature has reference.

\subsection{The Characteristics and Motives of Trust Financing}

The trust financing of listed companies in China means that the company, as a commissioner, entrusts the company's monetary funds (mainly raised funds) to securities companies, investment companies or other types of corporate enterprises according to an agreement, which is mainly used for loans, stock market investment. The entrusted property is mainly the company to raise funds, not the company's securities, fixed assets, intangible assets. And the trustee mostly represents securities company asset management department, excluding trusts, fund management companies. In the operation of funds, most funds invest in corporate loans, stock markets, few in money markets and foreign exchange markets (Sun, 2004).

According to $\mathrm{Ma}$ (2004), there are two reasons for trust management to occur. The first is that some companies engage in entrusted wealth management only after they have raised funds, due to the temporary idle funds and the high yield with temptation of entrusted wealth management in the stage of project construction. The second is that due to the sluggish industry under the project rate 
of return is low, some companies hope through financial statements entrusted to cover the financial statements. Chen \& Yan (2005) argued that the low financing costs through the issuance of shares and the absence of a hard-binding mechanism for the use of proceeds have contributed to the prevalence of trust financing. $\mathrm{Ba}$ (2001) pointed out that a large number of listed companies misappropriating money to entrust financial management exacerbated the "evil village" phenomenon. He believed that a large number of entrusted financial management practices in the market have the same market environment as the generation of "evil village". The first is serious flaws in the governance structure of listed companies. The second is the lack of necessary market constraints for listed companies to arbitrarily change their funding purposes. In addition to market forces and other external forces, it has the thrust of the enterprise, which focuses on the internal control of enterprises. Xu, Xue, \& Chen (2009) studied the influencing factors of entrusted wealth management of listed companies from 2000 to 2004 by means of Logistic regression. He found that there was a significant positive correlation between the free cash flow and the probability of entrusted wealth management. The higher the proportion of the largest shareholder, the lower probability happens about the entrusted wealth management.

\subsection{The Risk of Trust Financing}

Listed companies in the implementation of trust management meet many problems. Chen (2001) pointed out from the normative point of view that listed companies should have a cautious choice because buying financial projects may cause the financial system bubble. Liu \& Ren (2001) analyzed the harm done by entrusting wealth management to the real economy. It argues that the entrustment of wealth management by listed companies actually allows capital used in the virtual economy. As a result, the virtual economy expands too fast, and then the bubble burst, which eventually damages the real economy. Deng \& $\mathrm{He}$ (2003) thought that listed companies play a role as "setter" from raised funds to entrusting wealth management, which is a fraudulent act. Hou (2004) found that companies using entrusted financial management to raise funds play less efficient than the non-entrusted financial management company. Wang \& Gan (2004) pointed out that the risk of trusted financial management has been transitive, from a financial view. Wang (2004) found that listed companies were willful to put the raised funds into financial management. This action damaged the company's long-term interests and the interests of small and medium investors. Liu (2004) thought that many listed companies were in the name of trusted financial management, which would destroy the capital market financing functions and enlarge the market risk.

\subsection{The Literature Evaluation of Trust Financing}

At present, the article on entrusted financial management research in China explores the reasons, motives, risks, consequences and supervision methods of entrusted wealth management of listed companies from different perspectives. It 
mainly focuses on qualitative analysis with relatively few empirical studies. It also applies theory including agency theory, self-cash flow theory, game theory, information asymmetry theory, internal control theory and so on. Overall, most of the findings hold negative attitude towards entrusted financial management of listed companies, which is more harmful than profit. Most of the data used in empirical research concentrated in the period of 2000-2005. Those data still falls short of the empirical research on the entrusted wealth management of listed companies, especially the empirical research.

Most of the original sources of entrusted funds are the companies own idle funds, but the funds currently used by listed companies have been changed to raise funds. At present, the studies of financial products mostly start from the perspective of banks. They can explore the content of their product design, innovation and risk. However, there are few researches on the purchasers of wealth management products.

\section{The Literature Review of Raised Funds}

\subsection{The Literature Review on Reasons and Effects of Raised Funds Investment Changes}

\subsubsection{The Reasons of Raised Funds Investment Changes}

Liu et al. (2002) think that on the one hand, the change of the investment of raised funds is that listed companies randomly put together investment projects in order to misappropriate money; on the other hand, listed companies have no strategic plan for long-term development and blindly follow the trend of raised funds. Chen \& Chen (2005) shows the use of IPO raised funds by the largest shareholder of the proxy behavior. The stronger the largest shareholder proxy acts grab capacity, the lower the level of commitment IPO to raise funds, and the easier to change. Dong (2006) confirmed that the ownership structure of state-owned shares making the change of raised funds investment reflecting the interests of major shareholders. With the absolute advantage of controlling shareholders in information, the change of investment of raised funds is the embodiment of the interests of controlling shareholders. According to Wang, Gan, \& Xu (2002), the investment orientation of raised funds is not only the reason of listed companies themselves, but also the responsibility of investors, regulators and other market participants such as speculation by investors and doting of IPO companies in the market. The change is also related to the industries in which the enterprises are located (Wang, Gan, \& Xu, 2002), the market mechanism (Yang, 2003), and the external integrity restraint mechanism (Liu \& Dai, 2004).

\subsubsection{The Effect of Raised Funds Investment Changes}

There are three aspects to the effect analysis after the change of raised funds. The first is that it will have a positive effect. According to the research conducted by Huang \& Tang (2012), in the political affiliates, the performance of the enterprises after the change of investment proceeds is better. In some aspects, the in- 
vestment change related to the political affiliation is a benign one. The second is that the change has no big impact. Xu (2004) said that the project which the raised funds invested in cannot promote the growth of the business. The findings of Duan (2003) show that the announcement of the change of fund raising by listed companies does not have the information content, and the use of proceeds has not yet become an important basis for investors to make investment decisions. Therefore, there is no reference value for the investment change of the raised funds to the influence of the enterprise. However, the mainstream thinking still holds the view that changing direction will have a negative impact. Chen \& Hu (2010) took the listed companies listed on the A-share mainboard market of China from 1996 to 2006 as a sample. The research shows that the long-term operating performance of listed companies decreases significantly with the increase of the proportion of IPO financing investment. Yang \& Xue (2009) found that there was an interaction mechanism between the changes in the IPO investment and the post-IPO operating performance. Although the change was generally a change in good faith, investors were negative about the changes in the IPO investment. Liu \& Dai (2004) found that the listed companies generally changed their investment projects for raised funds. In the short run, those changes have obvious effects on the performance of listed companies.

\subsection{The Literature Review on Raising Funds Investment Efficiency}

\subsubsection{The Investment Efficiency of Raised Funds}

Xue \& Yang (2005) selected 314 A-share listed companies that made IPO in Shanghai Stock Exchange and Shenzhen Stock Exchange from 1996 to 2000 as a sample. Through the comparative study, they found that IPO raised funds for the development of the main business, in accordance with the plan committed to the commitment project, the full use of funds generated by the efficiency of respectively higher than the funds used for non-core business (diversification), changing investment project and idle funds. Domestic scholars have found that there is a significant correlation between idle raised funds by listed companies in China and the downturn of their investment performance. For example, Xiao (2008) found that there is a significant correlation between the idle raised funds by listed companies in China and the downturn in investment performance through the questionnaire survey. In terms of the forms of idle raised funds, listed companies tend to adopt trust management, investment in government bonds, or buying other companies' stocks. Wu \& Zhang (2010) used the data of SME sector in Shenzhen Stock Exchange of China from 2005 to 2008 and conducted empirical research on the investment efficiency of SMEs with the EVA theory. The results show that the investment behavior of SMEs in China has the characteristics of relatively large amount of investment, low capital dependence and low investment efficiency.

3.2.2. The Influencing Factors of the Raised Funds Investment Efficiency In terms of the investment efficiency of the raised funds, on the one hand, scho- 
lars conducted research based on the market mechanism and confirmed that the legal environment, audit quality (Zhai, 2010), local government intervention (Ma \& Gao, 2011), and local government (Hao, 2012) all affect the investment efficiency of listed companies. On the other hand, the remaining researches are based on the corporate governance structure. Wu (2006) found that the problems of principal-agent problems are common in the governance of listed companies, which makes the company inefficient or even unsuccessful, over-investment and serious project financing moral hazard. Other scholars prove that the quality of accounting information (Li, 2009a; Li, 2009b) and the level of accounting information disclosure (Liu \& Tian, 2011) also affect the efficiency of corporate investment.

\subsection{The Literature Evaluation of Raised Funds}

The research on raised funds mostly focuses on two points. The first one is the related research on the change of the raised funds, and the second one is the research on the investment efficiency of the raised funds. After the literature reading, we also found that the studies are on the single species, which are all focused on the IPO raised funds, despite the large number of researches. All of these studies lack the research on raised funds for proprietary projects after their listing, and the research on the idle part of raised funds. There is very little research on the raised funds for the purchase of wealth management products. Only a few studies revealed this phenomenon and criticized this behavior as unreasonable. There is no analysis of investment efficiency and corporate impact arising from the purchase behaviors of wealth management products by raised funds.

\section{Conclusion}

As a platform for investors and financiers to communicate and trade directly with each other, the value and significance of the capital market lie in facilitating the enterprises to raise idle funds in the society in order to facilitate the development of the real economy. However, contemporary Chinese capital market appears the phenomenon of "lawful but unreasonable" that listed companies make large-scale use of special fund-raising to buy bank wealth management products, which has also aroused the widespread concern and worries of investors and markets. On the one hand, the study of raising money to buy wealth management products can enrich the existing free cash flow theory. Jensen's theory of free cash flow suggests that free cash flow should be returned to shareholders while the investment project's NPV is less than 0 . However, the management of the company as the internal controller is apparently unwilling to return free cash flow investment, because of the self-interest maximization (Easterbrook, 1984), the impact of performance evaluation (Murphy, 1985) and overconfidence (Heaton, 2002), which will cause over-investment. For the managements or major shareholders, who go by the name of insiders, the cash they control is not only calculated according to the traditional formula, but also in- 
cludes the temporary idle raised funds. So, free cash flow can expand to manageable cash. On the other hand, this study can enrich the special fund-raising research. Through the study of raised funds to buy wealth management products to study the investment efficiency of raised funds and the impact on corporate performance and corporate value, broadened the research of raised funds. At the same time, the research on the special raised funds in idle and the use of raised funds by the enterprises after listing also make up for the blank of the traditional theoretical research focused on IPO raised funds. In addition, those studies can first provide value investors with a new perspective of financial analysis and stock-picking investment. That is, the use of special raised funds to purchase wealth management products can promote the increase of net profit. However, investable projects, poor growth, or serious suspicion of agency problems, which can act as a signal transmission, to assist investment decisions. Secondly, further regulate special to raise funds to provide the basis for the regulators. For regulators, the first step is to improve the audit procedures to guarantee the authenticity of the venture capital financing project. Regulators could require listed companies to provide practical conditions for the feasibility of project implementation, which is aim to prevent false declaration and over-raised. The second step is to strengthen the supervision of listed companies to purchase financial products from the banks in which the enterprise basic account located, to prevent the transfer of benefits. The purpose of all these regulatory measures is to effectively help the capital market effectively fulfill its own function of assisting the real economy.

However, there are still some shortcomings in this article. First of all, although the research object in this paper is defined as a special fund-raising, it is difficult to fully distinguish the sources of funds for the purchase of wealth management products in existing data. Second, subject to the difficulty of data collection, this article does not start the study from the perspective of empirical research on listed companies using raised funds to buy wealth management products for empirical test. Anyway, it is these deficiencies that provide new research perspectives for the follow-up study.

\section{References}

Ba, S. S. (2001). "Evil village” in the Misappropriating Game and Entrusted Financial Management. Modern Management Science, 5, 11-13.

Chen, C., \& Yan, G.-Q. (2005). Analysis and Risk Control of Listed Companies' Trust Management. North Finance, 5, 51-52.

Chen, Q., \& Hu, B. G. (2010). Changes in Investment Orientation and Fluctuations in Share Prices. Commercial Research, 8, 22-26.

Chen, S. (2001). Reflections on the Drawbacks of Entrusted Financial Management of Listed Companies. Journal of Hubei University for Nationalities (Philosophy and Social Sciences Edition), 4, 107-108+111.

Chen, W. B., \& Chen, X. Y. (2005). Acting Major Shareholder Issues and the Use of IPO Funds Raised. Nankai Management Review, 3, 4-8+36. 
Deng, X. Q., \& He, L. (2003). Behind the Blockbuster Transactions. Beijing: Securities Daily.

Dong, Y. (2006). Research on the Changes of Raised Funds' Aimed Projects in China. Master Thesis, Sichuan: Southwestern University of Finance and Economics.

Duan, T. Q. (2003). Research on Market Conduction Effect after Raised Funds Aimed Projects Changed. Master Thesis, Chongqing: Chongqing University.

Frank, E. (1984). Two Agency-Cost Explanations of Dividends. American Economic Review, 74, 650-659.

Hao, J. F. (2012). Political Linkages, Overinvestment and Corporate Performance-Based on the Background of Local Governmental Administrative Intervention. Industrial Technology Economics, 31, 123-134.

Heaton, J. B. (2002). Managerial Optimism and Corporate Finance. Financial Management, 31, 33-45.

Hou, Y. (2004). Empirical Research on the Causes and Influencing Factors of Entrusted Wealth Management of China Listed Companies. Master Thesis, Beijing: Tsinghua University.

Huang, X. J., \& Tang, L. X. (2012). Political Connection, Equity Financing and the Change of the Raised Funds-Based on the Empirical Study of Chinese Listed Companies. Soft Science, 26, 123-126.

Li, Q. Y. (2009a). The Quality of Accounting Information and the Efficiency of Capital Allocation-Evidence from Listed Companies in China. Nankai Management Review, 12, 115-124.

Li, Q. Y. (2009b). The Quality of Accounting Information, Auditing Supervision and Corporate Investment Efficiency-Evidence from Listed Corporations in China. Acta Auditing Research, 4, 65-73+51.

Liu, C., \& Tian, Y. (2011). An Empirical Study on the Disclosure Level of Accounting Information and Investment Efficiency of Listed Companies. Business Economics, 13, 108-109.

Liu, J. W., \& Ren, X. Y. (2001). Entrusted Management of Listed Companies Should Stop. Securities Daily.

Liu, Q. Y. (2004). The Status Quo, Reasons and Countermeasures of Intermediate Business in China's Commercial Banks. Journal of Chengdu University (Social Science Edition), 1, 14-15.

Liu, Q., Lu, M.-P., Xiao, X.-Q., \& He, C.-Y. (2002). Research on the Investment Orientation and Regulation of Raised Funds. Stock Market Herald, 1, 35-40.

Liu, S. B., \& Dai, W. H. (2004). The Study about the Changes of Raised Funds' Aimed Projects in China. Economic Research, 5, 88-97.

Ma, L. F., \& Cao, C. F. (2011). Changes in Institutional Environment, Local Government Intervention, Corporate Governance and IPO Funding Changes. Management World, 5, 127-139+148+188.

Ma, Y. H. (2004). Listed Companies Trust Financing Needs to Be Managed. Enterprise Reform and Management, 8, 10-11.

Murphy (1985). Corporate Finance and Managerial Remuneration: An Empirical Analysis. Journal of Accounting and Economics, 7, 11-42. https://doi.org/10.1016/0165-4101(85)90026-6

Sun, Z. Q. (2005). Studies of the Trust Financing of China's Listed Companies. Master Thesis, Hunan: Hunan University. 
Wang, L. H., \& Gan, S. D. (2004). Research on Trust Financing under the Condition of Asymmetric Information. Economic System Reform, 3, 116-118.

Wang, X. W. (2004). Research on the Phenomenon of Non-Compliant Financial Management of Listed Companies in China. North Economy, 9, 54-55.

Wang, X. Y., Gan, J. Y., \& Xu, H. (2002). Recognition on the Problems of Listed Company Changing the Raised Funds' Aimed Projects. Journal of Huazhong University of Science and Technology (Humanities and Social Sciences), 1, 69-72.

Wu, J.-M., \& Zhang, B.-C. (2010). Empirical Study on Investment Efficiency of Chinese Small and Medium-Sized Enterprises. Friends of Accounting, 1, 31-33.

Wu, Z. X. (2006). Effects of China's Listed Companies' Equity Incentives on Investment Efficiency. Productivity Research, 8, 209-211.

Xiao, G. (2008). Relationship between Idleness of Listed Companies and Investment Downturn-Based on the Analysis of the Questionnaire. Theory and Practice of Finance and Economics, 2, 63-68.

$\mathrm{Xu}$, P. (2004). Analysis of the Efficiency of Raised Funds by Listed Companies. China Securities Market Review, 3, 4-10+79.

Xu, Y. X., Xue, J., \& Chen, X. (2009). The Study of Commission Agency Problem from the Commission Rate of Return of Listed Companies. Nankai Management Review, 5, 101-108.

Xue, S., \& Yang, J. (2005). Impact of IPO Funds Investment and Use Efficiency on Equity Refinancing Costs. Proceedings of China and Asian Countries' Corporate Governance, Shanghai: The Chinese University of Hong Kong.

Yang, Q. W., \& Xue, Q. M. (2009). IPO Fund-Raising Changes in the Changes in Business Performance Changes and Market Reactions. Accounting Research, 4, 69-77+97.

Yang, X. L. (2003). An Empirical Study on the Reasons Why Listed Companies Change the Market Orientation of Raised Funds. Journal of Wuhan Institute of Technology, 3, 84-87.

Zhai, H. Y. (2010). Legal Environment, Auditing Quality and Corporate Investment Efficiency-Empirical Evidence from Chinese Listed Companies. South China Economy, 8, 29-40.

Zhou, J. N. (2006). Empirical Evidence and Theoretical Explanation to the Listed Companies' Over-Equity Financing. Stock Market Herald, 4, 66-71. 